\title{
Influence of Blanching on Antioxidant, Nutritional and Physical Properties of Bamboo Shoot
}

\author{
L. S. Badwaik ${ }^{1 *}$, G. Gautam ${ }^{1}$ and S. C. Deka ${ }^{1}$ \\ Received : $20^{\text {th }}$ November 2014 / Accepted : $30^{\text {th }}$ March 2015
}

\begin{abstract}
Quality of bamboo shoots gets deteriorate rapidly during storage and transportation due to enzymatic browning and microbial attack. Therefore, effect of blanching temperature $(75,85$ and $95^{\circ} \mathrm{C}$ ) and time (5, 10, 15, 20, 25 and $\left.30 \mathrm{~min}\right)$ on different physic-chemical properties of bamboo shoot cubes were assessed. Blanching time and temperature have significantly influenced the nutrients like protein, carbohydrate and reducing sugar contents. The highest changed in values of protein, carbohydrate and reducing sugar were reported from 3.42 to 2.24, 4.08 to 2.25, 1.33 to $0.87 \mathrm{~g} / 100 \mathrm{~g}$, respectively. The influence was less on ash and crude fiber. Retention of ascorbic acid, total phenolics and antioxidants were higher in $75^{\circ} \mathrm{C}$ and/or short time blanching (5- 10 min) which were gradually reduced at 85 and $95^{\circ} \mathrm{C}$ and/or long time blanching (20-30 min). The higher blanching temperature decreases in lightness value and long time blanching deteriorate the texture of bamboo shoot. Low temperature short time blanching was shown to result in better product quality with respect to physical properties besides nutrient retention.
\end{abstract}

Keywords: bamboo shoot, blanching, nutritional component, texture, colour

\section{INTRODUCTION}

India is one of the rich genetic resources of bamboo with 136 indigenous exotic species under 23 genera under cultivation. Bamboo shoots are low in fat and calorie but rich in different nutrients like protein, vitamin, mineral, fiber etc (Zheng et al., 2014). It also contains lignin and phenolic compounds which might contribute to its anti-microbial and anti-oxidant activity (Luo et al., 2012). Bamboo shoots are consumed in raw, canned, boiled, marinated, fermented, frozen, liquid and medicinal forms. However, the consumption pattern of bamboo shoots in most of the countries is traditional, non-standardized, seasonal and region-specific mostly in raw form (Choudhury, 2012).

Heat processing is applied to various vegetables to increase its shelf-life and nutritive value along with other properties while it also helps to reduce the anti-nutrient components (Pandey and Ojha, 2014). Blanching is a cooking process to stop various enzymatic reactions, reduce microbial load in food, soften tissues for an easier canning step and a shorter cooking time and eliminate intracellular air to prevent oxidation (Ruiz-Ojeda and Peñas, 2013). Heat treatment by hot water blanching has been increasingly used to control pests, insects and fungi rot. It also induces resistance to chilling injury during storage at low temperature (Lurie, 1998). Heat treatment inhibits disease incidences, respiration, ethylene production and various enzymatic activities of bamboo shoots during storage at $20^{\circ} \mathrm{C}$. Heat treatments like hot water blanching significantly delay tissue lignificaton (Luo et al., 2012).

Time and temperature of blanching may help enzymes like peroxidases to inactivate, which is one of the most heat stable enzymes and often 
used as a marker of completion of blanching (Barrett and Theerakulkait, 1995). Ascorbic acid, pigments like $\beta$-carotene are sensitive to heat treatment. Negi and Roy (2000) has reported that KMS treatment during blanching successfully reduces the loss of chlorophyll, carotene and ascorbic acid content of savory beet, amaranth and fenugreek followed by the low temperature drying which helps in the better retention of the pigments and vitamin $\mathrm{C}$. Blanching of soybean degrades its chlorophyll content but the loss of nutritive components including sugar, amino acid, and vitamin are minimal (Song et al., 2003). Low temperature long time (LTLT) blanching increases the final firmness of sterilized carrot, endive and green bean samples (Lin and Schyvens, 1995).

Blanching is a heat processing method applied to food and the changes in food during the heating process can be expected as loss in turgor in cells, loss of integrity of the cell membranes and partial degradation of cell wall components. Higher firmness of Brussel sprouts with increase in radical scavenging activity, total flavanoids and ascorbic acid content were observed after blanching operation at $50^{\circ} \mathrm{C}$ and $100^{\circ} \mathrm{C}$ for 5 and $3 \mathrm{~min}$, respectively. This may be attributed to loss of integrity of cell membranes and organelles (Olivera et al., 2008). However, the loss of soluble sugar of soybean during postharvest treatment like hot water blanching is due to leaching of sugar into water (Saldivar et al., 2010).

Usually bamboo shoots are boiled for particular time before consumption. The boiling time is dependent on the locality, traditional practices and the need for removal of bitterness of shoot. Rana et al., (2012) optimized the processing conditions by varying $\mathrm{NaCl}$ concentration, thickness of bamboo shoot, amount of $\mathrm{NaCl}$ solution and duration of treatment aiming reduction in cyanide content in fresh bamboo shoot. But the effect of boiling/ blanching time on nutritional components is not considered during the process. With regards to removal of anti-nutrient components during post-harvest treatment, some valuable nutrients also may get loss. The objective of this work is to find out the nutritional potential of some edible bamboo shoots of Assam and further investigate the change in nutritional composition (protein, carbohydrate, fat, fibre, ash) of fresh bamboo shoot during hot water blanching at different time-temperature combinations. Different quality parameters like colour, texture, ascorbic acid, total phenolic content and radical scavenging activity of fresh and blanched bamboo shoot samples were further analyzed.

\section{MATERIAL AND METHODS}

\section{Collection of raw materials and sample preparation}

Bamboo shoots of Dendrocalamus hamiltonni (Kako), Bambusa balcooa (Bhaluka), Bambusa pallida (Makal/ Bijuli), Bambusa tulda (Jati) species were collected from Tezpur, Nagaon and Karbi Anglong in Assam, India. The shoots were transported to the laboratory within 24 hours of collection, where shoots were defoliated and washed. The unwanted parts were removed and the soft edible portions were stored at $4^{\circ}$ $\mathrm{C}$ for further analysis. All the shoot samples were analyzed for moisture content, protein, fat, carbohydrate, crude fiber, ash, vitamin $\mathrm{C}$, total phenol and antioxidant activity.

\section{Blanching treatment}

The shoots of Bambusa balcooa species were used for this study. The soft edible portions were cut into uniform size of $1 \mathrm{~cm}^{3}$ and used for blanching treatment. For blanching treatment, shoots were immersed in a water bath at 75 , 85 and $95^{\circ} \mathrm{C}$ for $5,10,15,20,25$ and $30 \mathrm{~min}$ and collected after reaching pre-set time. After blanching, the samples were cooled in cooling water bath for 2 min and excess moisture was removed from the surface of the shoot by absorbent paper. An untreated sample was kept 
as a control. Fresh and blanched shoots were analyzed for moisture content, protein, fat, carbohydrate, crude fiber, ash, vitamin C, total phenol, antioxidant activity, texture and colour. During preliminary experiments the shoot was blanched at $75^{\circ} \mathrm{C}$ for $5 \mathrm{~min}$ and checked for the presence of enzyme polyphenol oxidase but was not found. Therefore all temperature and time combinations practiced as treatments were set above this level.

\section{Proximate analysis}

Bamboo shoots were analyzed for moisture, protein, fat, carbohydrate, crude fiber, and ash according to the standard AOAC methods (AOAC, 1990). Fat in the samples was determined by extracting a known weight of powdered sample with petroleum ether using Socs plus (SCS6). Crude fiber and protein in the samples were determined using Fibro plus (FES06) and Kel plus apparatus (Pelican Equipment, Chennai, India), respectively. The nitrogen content was converted to protein by multiplying with a factor of 6.25 .

\section{Estimation of vitamin C (L-Ascorbic Acid)}

Fresh and blanched bamboo shoots were weighed accurately to $5 \mathrm{~g}$ and extracted in $4 \%$ oxalic acid solution by homogenization followed by centrifugation at $3000 \mathrm{rpm}$ for $15 \mathrm{~min} .5 \mathrm{ml}$ of supernatant was collected and Vitamin $\mathrm{C}$ was estimated by titrating against $4 \%$ oxalic acid using 2, 6-dichlorophenolindophenols (DCPIP) as the indicator (Sadasivam and Theymdli, 1987). The standard solution of ascorbic acid was prepared for determining the standard curve.

\section{Estimation of total phenolic content}

The total phenolics in the sample were estimated using Folin-Ciocalteu reagent (FCR) procedure as described by Bray and Thorpe (1954). Bamboo shoot (1 g) was extracted with $10 \mathrm{ml}$ of $80 \%$ methanol and centrifuged at $10000 \mathrm{~g}$ at room temperature. Residue was reextracted (five times) with of $80 \%$ methanol and centrifuged. Supernatant was collected and evaporated to dryness and the residue was dissolved in $5 \mathrm{ml}$ of distilled water. From this mixture an aliquot of $0.2-2 \mathrm{ml}$ was taken in to a test tubes and the volume of $3 \mathrm{ml}$ was made using distilled water. FCR of $0.5 \mathrm{ml}$ was added into it and after 3 minutes $2 \mathrm{ml}$ of $20 \%$ sodium carbonate was added to each test tube. The mixture was heated on a water bath at 100 ${ }^{\mathrm{o}} \mathrm{C}$ for 1 minute and then cooled. Absorbance was measured at $750 \mathrm{~nm}$ in spectrophotometer, model Spectronic 20D+, (Thermo Scientific, USA). The results are expressed as mg phenol/ $100 \mathrm{~g}$ of sample as Gallic acid equivalent.

\section{Estimation of free radical scavenging activity}

To check the antioxidative property of the bamboo shoot $0.1 \mathrm{mM}$ of 2,2 diphenyl 1-picrylhydrazyl solution(DPPH) was prepared. DPPH is a commercial oxidising radical used to be reduced by antioxidants. The disappearance of the DPPH radical absorption at a particular wavelength is monitored by the reduction in optical density. Blanched sample were extracted in methanolic (5 gm in $20 \mathrm{ml}$ ) solution and supernatant obtained was centrifuged at 5000 $\mathrm{rpm}$ for $30 \mathrm{~min}$. After centrifuging $5 \mathrm{ml}$ of supernatant and $5 \mathrm{ml}$ of DPPH solution was mixed and kept under dark conditions for 30 minutes for complete reaction to take place. The anti radical activity was determined by spectrophotometer model Spectronic 20D+, (Thermo Scientific, USA) at $517 \mathrm{~nm}$, based on the reaction with stable radical DPPH (Khalaf et al., 2009). Control for the experiment was prepared by adding $5 \mathrm{ml}$ of DPPH and $5 \mathrm{ml}$ methanol (80\%). The DPPH radical scavenging activity was calculated according to the following equation.

$\%$ Free radical scavenger activity $=[($ Control absorbance - Sample absorbance)/ Control absorbance] $\times 100$ 


\section{Colour measurement}

The colour of bamboo shoot samples was measured using a Hunter Colour Lab (Ultrascan VIS, Hunter Lab. Inc., USA). The results were expressed in terms of $\mathrm{L}, \mathrm{a}$ and $\mathrm{b}$ values. $\mathrm{L}$, a and $\mathrm{b}$ values indicate lightness, redness $(+) /$ greenness $(-)$ and yellowness $(+)$ / blueness $(-)$, respectively (Papadakis et al., 2000).

\section{Texture measurement}

Texture (firmness) of fresh and blanched bamboo shoot were measured in Texture Analyser (TA-HDPlus, Stable Microsystems, UK) according to ASTM standard Method D882 (ASTM, 2001). The maximum force value is related to the firmness of the bamboo shoots. The measurements were performed in a Texture Analyser at a constant test speed of $0.5 \mathrm{~mm} /$ sec; however, pre-test and the post-test speeds were $1 \mathrm{~mm} / \mathrm{sec}$ and $5 \mathrm{~mm} / \mathrm{sec}$, respectively. The trigger force of $5 \mathrm{~g}, \mathrm{P} / 2$ cylindrical probe and 5 $\mathrm{kg}$ load cell was used for the test purpose.

\section{Statistical analysis}

The effect of blanching on nutritional components was examined by taking three replicates and data were reported as mean $\pm \mathrm{SD}$. Single factor ANOVA was used to determine the critical difference of means, and variance among the different samples at significance level $\mathrm{p} \leq 0.05$ (Steel and Torrie, 1980).

\section{RESULTS AND DISCUSSION}

\section{Nutritional analysis of bamboo shoot}

Four different varieties of bamboo shoots were analyzed to check their nutritional potential (Table 01). Moisture content for all the species was recorded above $90 \%$, which show the high perishability of shoot. The highest protein content of $3.42 \mathrm{~g} / 100 \mathrm{~g}$ was found in B. balcooa followed by $3.34 \mathrm{~g} / 100 \mathrm{~g}$ for B. pallida, 3.32 for B. tulda, and $3.28 \mathrm{~g} / 100 \mathrm{~g}$ for $D$. hamiltonii. Fat content of all species of shoots were found low and the values vary from 0.31 to $0.67 \mathrm{~g} / 100 \mathrm{~g}$. B. tulda shoot contains highest $(4.7 \mathrm{~g} / 100 \mathrm{~g})$ amount of carbohydrate compared to other varieties. The carbohydrate of $D$. hamiltonii, B. balcooa and B. pallida had estimated 4.46, 4.08 and $3.89 \mathrm{~g} / 100 \mathrm{~g}$, respectively. The ash content in the shoots ranged from 0.82-0.90 $\mathrm{g} / 100 \mathrm{~g}$ of fresh shoot. It was highest in B. pallida and lowest in B. Tulda. L-ascorbic acid of four varieties of bamboo shoots were varies from 1.39 to $2.72 \mathrm{mg} / 100 \mathrm{~g}$ and it was highest in B. balcooa. The above results are in-line with the nutrient components of Dendrocalamus giganteus Munro shoot carried out by Nirmala et al., (2008).

Table 01: Nutritional composition of different species of bamboo shoot on fresh weight basis

\begin{tabular}{lrrrr}
\hline Parameters & D. hamiltonii & B. balcooa & B. pallida & B. tulda \\
\hline Moisture (g/100g) & $90.71 \pm 1.46$ & $91.12 \pm 132$ & $91.56 \pm 1.18$ & $91.93 \pm 1.28$ \\
Protein $(\mathrm{g} / 100 \mathrm{~g})$ & $3.28 \pm 0.34$ & $3.42 \pm 0.12$ & $3.34 \pm 0.18$ & $3.32 \pm 0.22$ \\
Fat $(\mathrm{g} / 100 \mathrm{~g})$ & $0.67 \pm 0.05$ & $0.52 \pm 0.01$ & $0.31 \pm 0.07$ & $0.46 \pm 0.03$ \\
Carbohydrate $(\mathrm{g} / 100 \mathrm{~g})$ & $4.46 \pm 0.16$ & $4.08 \pm 0.36$ & $3.89 \pm 0.44$ & $4.70 \pm 0.27$ \\
Ash (g/100g) & $0.88 \pm 0.03$ & $0.86 \pm 0.07$ & $0.90 \pm 0.05$ & $0.82 \pm 0.04$ \\
Crude fiber $(\mathrm{g} / 100 \mathrm{~g})$ & $3.88 \pm 0.41$ & $3.51 \pm 0.32$ & $3.16 \pm 0.54$ & $3.92 \pm 0.25$ \\
Vitamin C (mg/100g) & $1.45 \pm 0.14$ & $2.72 \pm 0.18$ & $2.10 \pm 0.09$ & $1.39 \pm 0.21$ \\
Total phenols (mg/100g) & $88.23 \pm 4.38$ & $101.65 \pm 2.75$ & $79.85 \pm 3.98$ & $80.54 \pm 3.21$ \\
\% DPPH free radical scavenging activity & $23.12 \pm 1.34$ & $27.12 \pm 1.05$ & $19.17 \pm 0.98$ & $21.73 \pm 1.24$ \\
Reducing sugars $(\mathrm{g} / 100 \mathrm{~g})$ & $1.3 \pm 0.07$ & $1.33 \pm 0.11$ & $1.25 \pm 0.12$ & $1.26 \pm 0.05$ \\
\hline
\end{tabular}

All data are the mean \pm SD of three replicates. 
Total phenolics and antioxidant activity of $B$. balcooa shoot were reported as $101.65 \mathrm{mg} / 100 \mathrm{~g}$ and $27.12 \%$ DPPH radical scavenging activity and it was high compared to other three varieties of bamboo shoots. The results of total phenolics and antioxidant activity are in line with the study of Satya et al., (2009), but the values found during this study were comparatively less than reported values.

In view of nutritional status of all four species of bamboo shoot, B. balcooa found to be rich in protein, vitamin $C$, good amount of carbohydrates, crude fiber, reducing sugar etc and high amount of total phenolics and antioxidant activity. Meanwhile, B. balcooa is extensively used for preparing different dishes and fermented products. Therefore, for all further studies the shoots of B. balcooa were taken.

\section{Effect of blanching on nutritional component}

Nutritional components of fresh bamboo shoot were evaluated on the basis of blanching time and temperature and the results are shown in Table 02. From the Table it can be observed that blanching time and temperature have significantly influenced the nutrients like protein, carbohydrate and reducing sugar $(\mathrm{p} \leq$ 0.05). However, the influence was less on ash and crude fiber. Protein (amino acid), fat and carbohydrate (sugar) are important not only for the nutritional point of view but it also adds flavor to the food. But these components were reduced with blanching time and temperature. Blanching at $95^{\circ} \mathrm{C}$ markedly reduces the protein content of bamboo shoot in comparison to $75^{\circ} \mathrm{C}$ and $85^{\circ} \mathrm{C}$. At high temperature most of the labile protein gets denatured. Crude fat have been significantly affected after the blanching treatment $(p \leq 0.05)$. Fresh bamboo shoot contains $0.52 \mathrm{~g} / 100 \mathrm{~g}$ fat, after blanching for $30 \mathrm{~min}$ was reduced to $0.38,0.28$ and 0.19 $\mathrm{g} / 100 \mathrm{~g}$ at $75^{\circ} \mathrm{C}, 85^{\circ} \mathrm{C}$ and $95^{\circ} \mathrm{C}$ respectively. Duration of blanching treatment had been also affected the fat content. Blanching for 5-10 min has shown better retention of fat than long duration blanching (for 20-30 min). The reduction in fat might be due to melting and oxidation of fat at high heat treatment, which would allow it to transfer from sample to water during blanching at higher temperature and increasing time (Zhang et al., 2011).

Variation in carbohydrate and reducing sugar after hot water blanching was recorded and it can be observed that the maximum loss corresponds to the high temperature long duration blanching of $95{ }^{\circ} \mathrm{C}$ for $20-30 \mathrm{~min}$. Blanching treatment has a significant reduction $(p \leq 0.05)$ in carbohydrate and reducing sugar components by 4.08 to $2.25 \mathrm{~g} / 100 \mathrm{~g}$ and 1.33 to $0.87 \mathrm{~g} / 100 \mathrm{~g}$, respectively. Most of the sugar like glucose, fructose and sucrose was degraded during hot water blanching. The molecular size of sugar and duration of blanching affected the content of sugar and loss of this water soluble sugars might be correlated with leaching into water during blanching (Song et al., 2003). Crude fiber and ash content were almost remaining unaffected against blanching temperatures and time.

\section{Effect of blanching on L-ascorbic acid content}

Ascorbic acid content in fresh bamboo shoot was found to be $2.72 \mathrm{mg} / 100 \mathrm{~g}$. Blanching temperature significantly reduced the ascorbic acid content of bamboo shoot $(\mathrm{p} \leq 0.05)$ (Figure $01)$. Retention of ascorbic acid is higher in 75 ${ }^{\circ} \mathrm{C}$ which was gradually reduced at $85^{\circ} \mathrm{C}$ and $95^{\circ} \mathrm{C}$. It is also affected by the duration of blanching. Blanching for short time (5-10 min) retain more ascorbic acid while at 20-30 min the losses were high. Loss of ascorbic acid might be due to the leaching of content into water. L-ascorbic acid is very soluble in water and are not stable at high temperature (Zhang et al., 2011). Vegetable tissue suffers various changes in cell permeability and vacuole membrane upon high temperature treatment, which leaches the nutrients. Similar results were found on by Olivera et al., (2008) on Brussels sprouts during 
blanching. However, disruption of cell during blanching leads to the migration of ascorbic acid into the blanching medium which may accounts for the high loss of ascorbic acid from the vegetables (Maharaj and Sankat, 1996).

\section{Effect of blanching on total phenolic content}

Fresh bamboo shoot showed the total phenolic content of $101.65 \mathrm{mg} / 100 \mathrm{~g}$ which degraded during blanching. The total phenolic value for the samples blanched at 75,85 and $95^{\circ}$ $\mathrm{C}$ for 10,20 and $30 \mathrm{~min}$ are indicated in the Figure 02. The results clearly indicate that there is a significant loss of phenolic content with increase in temperature and duration of blanching ( $\mathrm{p} \leq 0.05)$. Maximum loss can be observed at $95^{\circ} \mathrm{C}$ for $30 \mathrm{~min}$ of blanching and the highest retention of phenolics were reported at $75^{\circ} \mathrm{C}$ for $5 \mathrm{~min}$. At the end of blanching treatment, the retention of phenolic at 75,85 and $95^{\circ} \mathrm{C}$ were $59.57,45.26$ and $39.34 \mathrm{mg} / 100 \mathrm{~g}$ respectively. High intensity heat treatment leads to the maximum loss of phenolic content which may be due to several reasons like thermal degradation, leaching or diffusion of component into water etc (Gonçalves et al., 2010). Similar results were reported by Jaiswal et al., (2012) during blanching of cabbage. Enzyme like PAL (phenylalanine ammonia-lyase), PPO (polyphenol oxidase) plays an important role during phenol synthesis in plant. PAL is the first key enzyme in the biosynthesis of the phenolic component. Increase activity of PAL leads to the increase in synthesis of phenols (Luo et al., 2012). Thus it can be attributed that during heat treatment these enzymes gets inactivated which leads to the reduction of phenolic components.

\section{Effect of blanching on free radical scavenging activity}

DPPH is a stable free radical which is used to interpret the antioxidative property of sample. Antioxidant property of fresh and blanched sample were assayed and shown in Figure 03.

The profile obtained after blanching of bamboo shoot, showing a decreasing antioxidative activity after blanching operation. Graph depicts the significant loss of antioxidative property as the temperature and time of the blanching increases $(p \leq 0.05)$. Antioxidative property of bamboo shoot is usually contributed by different phytochemicals such as phenols, tocopherol, ascorbic acid and their synergistic effects. Thus, antioxidative capacity cannot be correlated with a single compound, but attributed to synergistic and additive effects of different inherent phytochemicals (Schmitz-Eiberger and Blanke 2012). Different studies have suggested that not only the phenolic content but the molecular structure of them also affects the antioxidative property (Molyneux, 2004).

\section{Effect of blanching on colour of the bamboo shoot}

Colour is one of the most important parameter which indicates the quality and freshness of any food. Colour parameter of fresh and blanched bamboo shoot at different time and temperature are shown in Figure 04. The $\mathrm{L}$ value depicts the lightness of the sample. Fresh sample has having a higher $L$ value (71.26) compared to blanched samples which were decreased further as the blanching time and temperature increased. Bamboo shoots blanched at $75^{\circ} \mathrm{C}$ and $85{ }^{\circ} \mathrm{C}$ have shown a little colour change with increase in blanching time. While there were more changes in colour values in the samples blanched at $95^{\circ} \mathrm{C}$. At higher blanching temperature (85$95^{\circ} \mathrm{C}$ ), excessive loss in the natural colour pigments and decreased in lightness of the shoot were observed. This might be due to the non enzymatic browning of bamboo shoots due to high temperature treatment. Gonçalves et al., (2010) follows the same trends of decrease in $\mathrm{L}$ and a value with increasing blanching time for carrot, but $b$ value were not in line with this study. In this case, $b$ value increased with temperature and time of blanching and this might be due to more yellowness form on blanched shoots at high temperature. Blanching alters the chloroplast integrity where the 
chlorophyll pigments are embedded and results temperature of blanching progresses (Llano et in the formation of pheophytin as the time and al., 2003).

Table 02: Effect of blanching on different nutritional component

\begin{tabular}{|c|c|c|c|c|c|c|c|c|c|c|c|c|}
\hline \multirow[b]{2}{*}{ Parameters } & \multirow[b]{2}{*}{$\begin{array}{l}\text { Temp. } \\
\left({ }^{\circ} \mathrm{C}\right)\end{array}$} & \multicolumn{11}{|c|}{ Blanching Time (Min) } \\
\hline & & 0 & 5 & 10 & 15 & 20 & 25 & 30 & Means & & $\mathrm{CD}$ & \\
\hline \multirow{4}{*}{$\begin{array}{l}\text { Protein } \\
(\mathrm{g} / 100 \mathrm{~g})\end{array}$} & 75 & 3.42 & 3.31 & 3.26 & 3.17 & 3.02 & 2.95 & 2.9 & 3.15 & \multirow{4}{*}{ 兲 } & \multirow{4}{*}{ 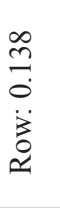 } & \multirow{4}{*}{ 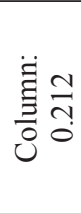 } \\
\hline & 85 & 3.42 & 3.23 & 3.14 & 3.05 & 2.84 & 2.72 & 2.54 & 2.99 & & & \\
\hline & 95 & 3.42 & 3.15 & 3.04 & 2.86 & 2.58 & 2.37 & 2.24 & 2.81 & & & \\
\hline & Means & 3.42 & 3.23 & 3.15 & 3.03 & 2.81 & 2.68 & 2.56 & 2.98 & & & \\
\hline \multirow{4}{*}{$\begin{array}{l}\text { Fat } \\
(\mathrm{g} / 100 \mathrm{~g})\end{array}$} & 75 & 0.52 & 0.48 & 0.45 & 0.41 & 0.4 & 0.38 & 0.38 & 0.43 & \multirow{4}{*}{ 兲 } & \multirow{4}{*}{ 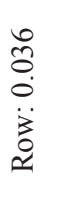 } & \multirow{4}{*}{ 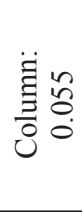 } \\
\hline & 85 & 0.52 & 0.44 & 0.41 & 0.37 & 0.33 & 0.3 & 0.28 & 0.38 & & & \\
\hline & 95 & 0.52 & 0.39 & 0.37 & 0.31 & 0.27 & 0.22 & 0.19 & 0.32 & & & \\
\hline & Means & 0.52 & 0.44 & 0.41 & 0.36 & 0.33 & 0.30 & 0.28 & 0.38 & & & \\
\hline \multirow{4}{*}{$\begin{array}{l}\text { Carbohydrate } \\
(\mathrm{g} / 100 \mathrm{~g})\end{array}$} & 75 & 4.08 & 3.92 & 3.83 & 3.73 & 3.65 & 3.57 & 3.43 & 3.74 & \multirow{4}{*}{ 声 } & \multirow{4}{*}{ 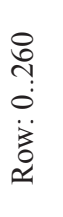 } & \multirow{4}{*}{ 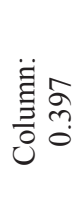 } \\
\hline & 85 & 4.08 & 3.77 & 3.71 & 3.52 & 3.37 & 3.24 & 3.11 & 3.54 & & & \\
\hline & 95 & 4.08 & 3.66 & 3.54 & 3.3 & 3.07 & 2.54 & 2.25 & 3.21 & & & \\
\hline & Means & 4.08 & 3.78 & 3.69 & 3.52 & 3.36 & 3.12 & 2.93 & 3.50 & & & \\
\hline \multirow{4}{*}{$\begin{array}{l}\text { Ash } \\
(\mathrm{g} / 100 \mathrm{~g})\end{array}$} & 75 & 0.86 & 0.86 & 0.85 & 0.85 & 0.84 & 0.84 & 0.84 & 0.85 & \multirow{4}{*}{ 袁 } & \multirow{4}{*}{ 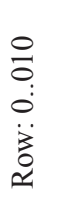 } & \multirow{4}{*}{ 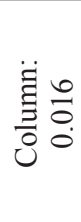 } \\
\hline & 85 & 0.86 & 0.85 & 0.84 & 0.83 & 0.83 & 0.83 & 0.83 & 0.84 & & & \\
\hline & 95 & 0.86 & 0.82 & 0.81 & 0.8 & 0.8 & 0.79 & 0.79 & 0.81 & & & \\
\hline & Means & 0.86 & 0.84 & 0.83 & 0.83 & 0.82 & 0.82 & 0.82 & 0.83 & & & \\
\hline \multirow{4}{*}{$\begin{array}{l}\text { Crude fiber } \\
(\mathrm{g} / 100 \mathrm{~g})\end{array}$} & 75 & 3.51 & 3.51 & 3.51 & 3.51 & 3.51 & 3.51 & 3.51 & 3.51 & \multirow{4}{*}{ 弯 } & \multirow{4}{*}{$\begin{array}{c} \pm \\
8 \\
0 \\
0 \\
\ddot{3} \\
0 \\
0\end{array}$} & \multirow{4}{*}{ 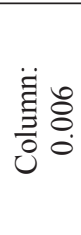 } \\
\hline & 85 & 3.51 & 3.51 & 3.51 & 3.51 & 3.51 & 3.5 & 3.5 & 3.51 & & & \\
\hline & 95 & 3.51 & 3.51 & 3.5 & 3.5 & 3.5 & 3.5 & 3.5 & 3.50 & & & \\
\hline & Means & 3.51 & 3.51 & 3.51 & 3.51 & 3.51 & 3.50 & 3.50 & 3.51 & & & \\
\hline \multirow{4}{*}{$\begin{array}{l}\text { Reducing } \\
\text { sugars } \\
(\mathrm{g} / 100 \mathrm{~g})\end{array}$} & 75 & 1.33 & 1.28 & 1.22 & 1.18 & 1.14 & 1.1 & 1.07 & 1.19 & \multirow{4}{*}{ 悲 } & \multirow{4}{*}{ 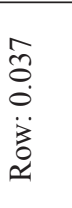 } & \multirow{4}{*}{ 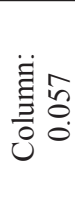 } \\
\hline & 85 & 1.33 & 1.23 & 1.2 & 1.15 & 1.11 & 1.04 & 0.98 & 1.15 & & & \\
\hline & 95 & 1.33 & 1.18 & 1.14 & 1.09 & 1.06 & 0.94 & 0.87 & 1.09 & & & \\
\hline & Means & 1.33 & 1.23 & 1.19 & 1.14 & 1.10 & 1.03 & 0.97 & 1.14 & & & \\
\hline
\end{tabular}

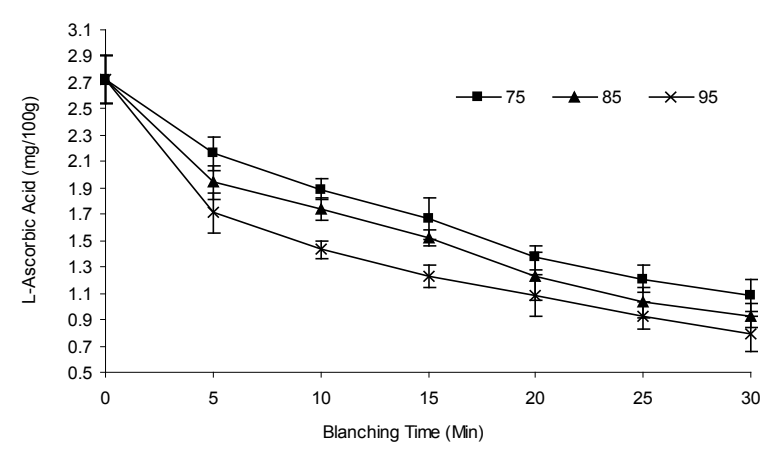

Figure 01: Effect of blanching temperature on ascorbic acid content (Vertical bars indicate the standard error at $\mathbf{p} \leq \mathbf{0 . 0 5}$ )

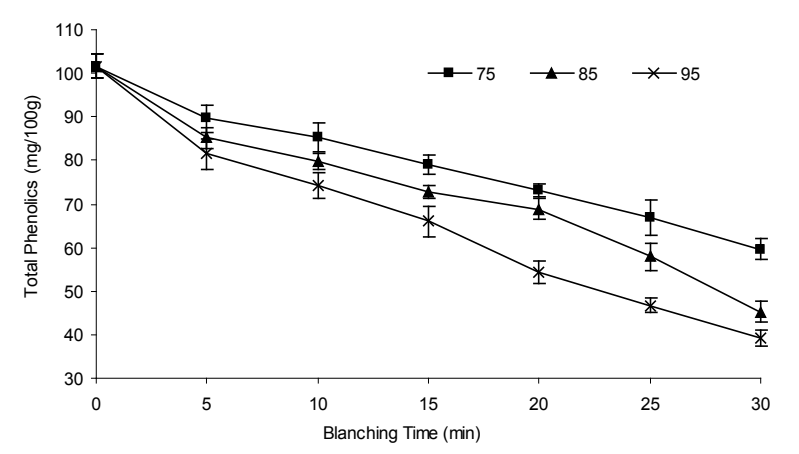

Figure 02: Effect of blanching temperature on total phenolic content (Vertical bars indicate the standard error at $p \leq \mathbf{0 . 0 5}$ ) 


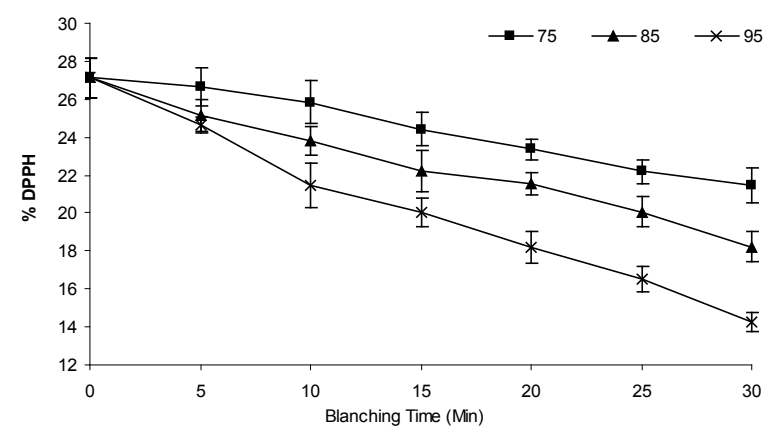

Figure 03: Effect of blanching temperature on free radical scavenging activity (Vertical bars indicate the standard error at $p \leq 0.05$ )
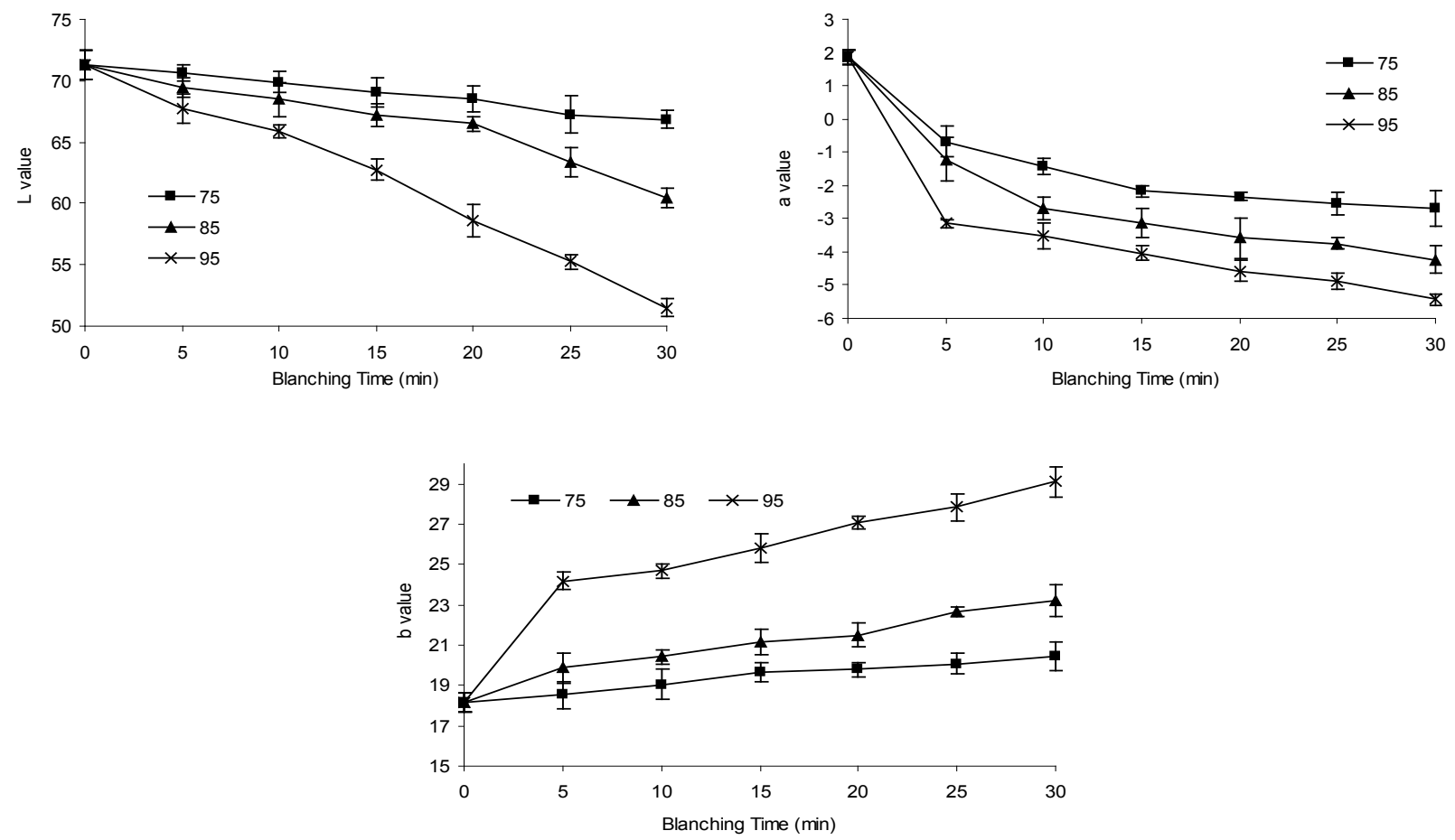

Figure 04: Effect of blanching temperature on colour of bamboo shoot (Vertical bars indicate the standard error at $p \leq 0.05$ )

\section{Effect of blanching on texture}

Firmness of bamboo shoots continuously decreased with increasing time and temperature of blanching. Fresh bamboo shoot exhibited firmness of $547.83 \mathrm{~g}$. The effect of blanching temperatures $\left(75-95^{\circ} \mathrm{C}\right)$ and time $(5-30 \mathrm{~min})$ on bamboo shoot texture is shown in Figure 05. Textural loss was found to be more in first 5 minutes of blanching which consistently increased with increase in temperature and time. Most of the degradation of texture was occurred during 30 minutes of blanching at $95^{\circ}$ C (Gonçalves et al., 2010). Firmness of the fresh and blanched bamboo shoot can be attributed to the loss of lignin and cellulosic components of cell wall. There is decrease in lignin and cellulose with increase in time and temperature of blanching (Miao et al., 2011). 


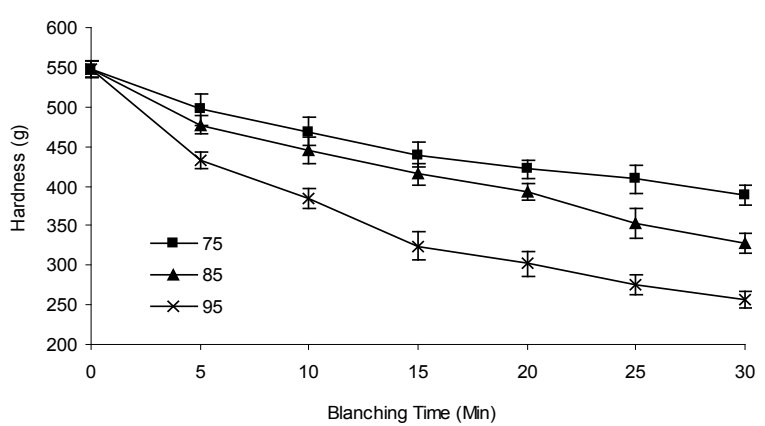

Figure 05: Effect of blanching temperature on texture of bamboo shoot (Vertical bars indicate the standard error at $\mathbf{p} \leq \mathbf{0 . 0 5}$ )

Softening of tissue after hot water blanching is due to the decomposition of pectic substances with some other biochemical changes. Significant changes in the textural properties of blanched bamboo shoot can be observed at different temperature and time $(\mathrm{p} \leq 0.05)$. Bamboo shoots blanched for 5 to 10 min have shown better retention of textural properties than 20 to 30 min of blanching. At the end of 30 min of blanching the retention of texture at 75 , 85 and $95{ }^{\circ} \mathrm{C}$ were $70.74,59.84$ and $46.86 \%$, respectively. The textural behavior is consistent with the results found by Zheng et al. (2014).

\section{CONCLUSION}

Blanching in hot water was carried out in order to inactivate various enzymes and to improve the quality and to increase the shelf-life of vegetable. Effect of hot water blanching on different physical and nutritional quality like total soluble sugars, protein, dietary fiber, fat vitamin, ascorbic acid, phenolic content and radical scavenging activity were evaluated. Blanching of bamboo shoot leads to degradation of various nutrients. Loss was maximum at $95^{\circ} \mathrm{C}$ for $20-30 \mathrm{~min}$ and minimum at $75^{\circ} \mathrm{C}$ for 5-10 min of blanching. Texture was also affected by the blanching operation. Blanching results in soft texture, while there was decreased in lightness and increase in greenness and yellowness observed. Loss of antioxidative property, total phenolic content and ascorbic acid might be related to the migration or leaching of component into the water. Proper combination of time and temperature of blanching is very important to retain the nutrients and quality of bamboo shoot. Low temperature and short time blanching have better retention of the entire nutritional component along with colour and textural properties. Therefore low temperature treatment with short duration was most suitable method of blanching.

\section{ACKNOWLEDGEMENT}

Authors are thankful to University Grants Commission (UGC), New Delhi for providing financial support.

\section{REFERENCES}

AOAC. (1990). Approved methods of Association of Official Analytical Chemists, $15^{\text {th }}$ ed. Arlington, VA, USA.

ASTM (2001). Standard test method for static modulus of elasticity and Poisson's ratio of concrete in compression. American Society for Testing and Materials, West Conshohochen. 
Barrett, D.M. and Theerakulkait, C. (1995). Quality indicators in blanched, frozen, stored vegetables. Food Technology, 49(1): 62-65.

Bray, H.G. and Thorpe, W.V. (1954). Analysis of phenolic compounds of interest in metabolism. Methods of Biochemical Analysis, 1: 27-52.

Choudhury, D., J.K. Sahu, and G.D. Sharma, (2012). Value addition to bamboo shoots: a review. Journal of Food Science and Technology, 49(4): 407-414.

Gonçalves, E. M., Pinheiro, J., Abreu, M., Brandão, T. R. S. and Silva, C. L. (2010). Carrot (Daucus carota L) peroxidase inactivation, phenolic content and physical changes kinetics due to blanching. Journal of Food Engineering, 97(4): 574-581.

Jaiswal, A. K., Gupta, S. and Abu-Ghannam, N. (2012). Kinetic evaluation of colour, texture, polyphenols and antioxidant capacity of Irish York cabbage after blanching treatment. Food Chemistry, 131(1): 63-72.

Khalaf, N. A., Shakya, A. K., Al-Othman, A., El-Agbar, Z. and Farah, H. (2009). Antioxidant activity of some common plants. Turkish Journal of Biology, 32: 51-55.

Lin, Z. \& Schyvens, E. (1995). Influence of blanching treatments on the texture and color of some processed vegetables and fruits. Journal of Food Processing and Preservation, 19(6): 451465.

Llano, K. M., Haedo, A. S., Gerschenson, L. N. and Rojas, A. M. (2003). Mechanical and biochemical response of kiwifruit tissue to steam blanching. Food Research International, 36(8): 767775.

Luo, Z., Feng, S., Pang, J., Mao, L., Shou, H. and Xie, J. (2012). Effect of heat treatment on lignification of postharvest bamboo shoots (Phyllostachys praecox f. prevernalis). Food Chemistry, 135(4): 2182-2187.

Lurie, S., (1998). Postharvest heat treatments. Postharvest Biology and Technology, 14(3): 257269.

Maharaj, V. and Sankat, C. K. (1996). Quality changes in dehydrated dasheen leaves: effects of blanching pre-treatments and drying conditions. Food Research International, 29(5): 563568.

Miao, M., Wang, Q., Zhang, T. and Jiang, B. (2011). Effect of high hydrostatic pressure (HHP) treatment on texture changes of water bamboo shoots cultivated in China. Postharvest Biology and Technology, 59(3): 327-329.

Molyneux, P., (2004). The use of the stable free radical diphenylpicrylhydrazyl (DPPH) for estimating antioxidant activity. Songklanakarin Journal of Science and Technology 26(2): 211-219.

Negi, P.S. and Roy, S.K. (2000). Effect of blanching and drying methods on $\beta$-carotene, ascorbic acid and chlorophyll retention of leafy vegetables, LWT-Food Science and Technology, 33(4): 295-298. 
Nirmala, C. and Sharma, M. L. (2008). A comparative study of nutrient components of freshly harvested, fermented and canned bamboo shoots of Dendrocalamus giganteus Munro. Bamboo Science and Culture, 21(1): 41-47.

Olivera, D. F., Vina, S. Z., Marani, C. M., Ferreyra, R. M., Mugridge, A., Chaves, A. R. and Mascheroni, R. H. (2008). Effect of blanching on the quality of Brussels sprouts (Brassica oleracea L. gemmifera DC) after frozen storage. Journal of Food Engineering, 84(1): 148155.

Pandey, A.K. and Ojha, V. (2014). Precooking processing of bamboo shoots for removal of antinutrients. Journal of Food Science and Technology, 51(1): 43-50.

Papadakis, S.E., Abdul-Malek, S., Kamdem, R. E. and Yam, K. L. (2000). A Versatile and inexpensive technique for measuring colour of foods. Food Technology, 54(12): 48-51.

Rana, B. Awasthi, P. and Kumbhar, B.K. (2012). Optimization of processing conditions for cyanide content reduction in fresh bamboo shoot during $\mathrm{NaCl}$ treatment by response surface methodology. Journal of Food Science and Technology, 49(1): 103-109.

Ruiz-Ojeda, L.M. and Peñas, F. J. (2013). Comparison study of conventional hot-water and microwave blanching on quality of green bean. Innovative Food Science and Emerging Technologies, 20: 191-197.

Sadasivam, S. and Theymdli, B. (1987). Practical Manual in Biochemistry, Tamil Nadu Agricultural University Coimbatore.

Saldivar, X., Wang, Y. J., Chen, P. and Mauromoustakos, A. (2010). Effects of blanching and storage conditions on soluble sugar contents in vegetable soybean. LWT-Food Science and Technology, 43(9): 1368-1372.

Satya, S., Singhal, P., Prabhu, V. G., Bal, L. M. and Sudhakar, P. (2009). Exploring the nutraceutical potential and food safety aspect of bamboo shoot of some Indian species. VIII World Bamboo Conference, Bangkok, Thailand. P: 78-88.

Schmitz-Eiberger, M.A. and Blanke, M. M. (2012). Bioactive components in forced sweet cherry fruit (Prunus avium L.), antioxidative capacity and allergenic potential as dependent on cultivation under cover. LWT-Food Science and Technology, 46(2): 388-392.

Song, J.Y., An, G. H. and Kim, C. J. (2003). Color, texture, nutrient contents, and sensory values of vegetable soybeans [Glycine max (L.) Merrill] as affected by blanching. Food Chemistry, 83(1): 69-74.

Steel, R.G.D. and Torrie, J.H. (1980). Principles and Procedures of Statistics: A Biometric Approach. $2^{\text {nd }}$ Ed. McGraw Hill Book Co. Inc., New York:

Zhang, J.J., Ji, R., Hu, Y. Q., Chen, J. C. and Ye, X. Q. (2011). Effect of three cooking methods on nutrient components and antioxidant capacities of bamboo shoot. Journal of Zhejiang University Science B, 12(9): 752-759.

Zheng, J., Zhang, F., Song, J., Lin, M. and Kan, J. (2014). Effect of blanching and drying treatments on quality of bamboo shoot slices. Journal of Food Science and Technology, 49(2): 531-540. 